\title{
Service Quality Dimensions of Higher Education Institutions and Students’ Satisfaction: Bangladesh Perspective
}

\author{
Dhiman Barua ${ }^{1}, \&$ Md. Sarwar Uddin, $\mathrm{PhD}^{2}$ \\ ${ }^{1}$ Assistant Professor, Faculty of Business Administration, BGC Trust University Bangladesh, Chandanaish, Chittagong, \\ Bangladesh \\ ${ }^{2}$ Associate Professor, Faculty of Business Administration, BGC Trust University Bangladesh, Chandanaish, Chittagong, \\ Bangladesh
}

Correspondence: Md. Sarwar Uddin, PhD, Associate Professor, Faculty of Business Administration, BGC Trust University Bangladesh, Chandanaish, Chittagong, Bangladesh.

Received: January 6, 2021

Accepted: January 28, 2021

Available online: February 8, 2021

doi:10.11114/ijsss.v9i2.5126

URL: https://doi.org/10.11114/ijsss.v9i2.5126

\begin{abstract}
Higher education institutions (HEI's), both public and private are increasingly focusing on meeting students' demand as students' perception on quality of higher educational services are becoming more important. This paper is mainly attempted to examine the relationship between service quality dimensions (tangibles, reliability, responsiveness, assurance and empathy) and students' satisfaction. To conduct the study, a total number of 207 respondents were taken as sample from eight universities including four public universities located in Dhaka and Chittagong. Five point Likert scale type questionnaire was used to collect the data. In this study, some statistical measures such as mean, standard deviation, correlation were used to analyze the linkage. The results found that there is a positive relation between service quality dimensions and students' satisfaction specifically tangibles and reliability have significant influence on students' satisfaction. The study also revealed that responsiveness, assurance and empathy have insignificant relation with students' satisfaction. This paper concludes with limitation and future research direction.
\end{abstract}

Keywords: students' satisfaction, service quality, higher education institutions

\section{Introduction}

Higher education is generally used to comprehend the entire range and dynamics of post-secondary higher education. In Bangladesh, higher education is spreading across the country rapidly in recent time. As of March 2020, There are 151 universities of which 46 are public and 105 are private (UGC website). After passing private university act, 1992, the rise of private universities is creating more options to students as well as competition among universities. It is difficult for universities both private and public to receive competitive advantage in the target market as those institutions are characterized by a very complex and sophisticated structure. Student satisfaction has become a major challenge for the universities and it is treated as a major source of competitive advantage. To build and maintain better relationships with students, HEIs are searching for innovative ways as to get greater benefit in future. (Angel et al., 2009)

Satisfaction is a metric focused on the extent of expectations as well as the perceived results. It can arise as a feeling in a person (Kotler \& Clarke, 1987). There are several kinds of stakeholders of educational entities that vary from internal to external. The students of a educational sector are considered to be the most significant stakeholder for society since it utilizes the mechanism of consistency consequences on them by applying input, process, output on them. As we step towards being a more global economy, there is a need for more successful bridges between non-academic stakeholders (employers, society, parents, etc) and academic institutions, and the partnership between all stakeholders relies on the happiness of the students (Khan et al. 2011).Social factors (student- teacher relationship, student- administration relationship, student-student relationship) and physical factors (modern class room, library, transport, computer lab, wifi facility, canteen, and support service) have direct impact on the students' satisfaction to the institution (Uka, 2014). To understand the level of students' satisfaction, quality of service has revealed a continuous and increased attention from leadership management (Mark, 2013).

Service quality is an evaluation of service receiver about the overall performance of service delivery of an institution. It is a measurement of comparing customers' expectation with delivered service which influence on customer's satisfaction 
(Kang et al., 2004). Service quality can be hampered due to poor input (weak students), poor delivery service (lack of concentration on quality teaching), poor internal evaluation (lack of attention on performance standard, evaluation and staff motivation) and quality development (neglect of students' skill development) (Crawford and Shulter, 1999).

Ensuring standard service quality to attract and retain students through their satisfaction becomes a significant issue of higher education institutions. Very few studies were conducted to assess the students' satisfaction on the service quality of HEI considering both private and public in Bangladesh. The focus of this study is to fulfill the gap.

\section{Literature Review}

\subsection{Students' Satisfaction}

Students' satisfaction is an indicator of the institutions' responsiveness to the needs of the students and measures the success, acceptance and vitality of the institution to the students as well as to the society. Oxford dictionary defined satisfaction as the good feelings that a person have when he have achieved something or when something that he wanted to happen does happen; something that gives him this feelings. According to Zeithamul (1988), satisfaction is the resultant outcome of institutions' administration as well as educational systems coherent performance. Elliott\& Shin (2002) defined student satisfaction as the favorability of a student's judgment of the various outcomes and experience gathered during his campus life. A student can be treated as satisfied student if he feels that the lesson meets his demand and expectation and this leads the student to exert greater effort, increase positive attitude towards the lesson and to attend other courses in future (Gecer, 2013).

\subsection{Service Quality}

The effect of the standard of service quality in the educational field as well as higher learning is not necessarily only something that is valuable, but is also an important prerequisite criterion of excellence. Positive perceptions on service quality results satisfaction of students and satisfied students attract new students to the institutions. (Alves and Rapaso, 2010). At present, universities are giving more attention in the quality of service, especially those who are delivering new strategies to improve quality with reference to the students' satisfaction (Mark 2013).

Asaduzzaman et al., (2013) defined service quality of a university as the overall assessment on the services they received that is element of their learning experience. He identified tangibles as the most influential factor to evaluate the students' satisfaction on the service quality which include faculty and environment related factors namely cleanliness, temperature of room, computer lab and internet facility, appearance of building, appearance of personnel, parking facility. Jain(2011) identified two important dimensions, namely- program quality and quality of life to understand the students' perceptions of service quality with eight sub dimensions (academic facility, quality of input, non-academic process, support facilities, curriculum, industry interaction, quality of interaction, campus) to reflect the specific aspects of a service delivery process.

Gronroos (1984) reveals that service quality encompass three inter-connected dimensions. The first one is the technical quality which relates to the performance or what is being provided to or what the consumer gain from the service. The second factor is focused on the functional quality that a treatment is being provided in a way that satisfies the expectation of the customer. Finally, the corporate which relates to the store's reputation which is primarily focused on both the consistency of technical, creative and to some degree other aspects such as conventional marketing practices. Das and Hoque (2013) studied on faculty service in tertiary education and observed that quality faculty service specifically faculty discipline, teaching method, faculty attitude, teaching quality are some effective factors to attract and motivate students. Athiyaman (1997) observed that consumer satisfaction has similarity with attitude and which resulting from an evaluation of a specific consumption experience. He used eight factors to assess higher education service quality namely, good teaching, availability of staff for student consultation, library services, class size, recreation facility, computer lab facility, level of student content and student workload.

\subsection{Student Satisfaction and Service Quality}

Huda et al., (2010) stated that students' satisfaction on service provided by the universities depends on some variables like the tuition fees, classroom, course curriculum, time provided the teachers, class time, library and computer lab facility, location of the university, extra curriculum activities. Elliot and Shin (2002) observed that skilled faculty, quality of instruction, safe and secured campus, bearable tuition fee, proper classes, computer lab facility, proper infrastructure system, fairness and transparency of faculty are associated with the students' satisfaction on the institution. Malik, et al. (2010) mentioned that tangibility, reliability, assurance and empathy have a significant impact on the students' satisfaction from the institution and students expect the cooperation, kindness of administrative staff and responsiveness of the educational system. Faruky (2012) identified some factors to measure the students' satisfaction such as- faculty credentials, students' personal development and safety measurement, academic and supportive facilities, social status of the university and showed that faculty credential is the most influential factor affecting the students' satisfaction on 
private universities in Bangladesh.

Majid et al., (2000) focused on teaching quality, teaching methods, teaching aid and supportive facilities to assess the students' satisfaction. Emercy et al., (2001) considered students as the product of the academic institutions. Students and academic institutions depend on each other. Students rely on institutions to gather knowledge, obtain degree and to open career path, on the other hand institutions need students for meeting financial demand. Khan et al., (2011) observed a significant relationship of reliability, assurance, responsiveness and empathy with students' satisfaction, while tangible has less influence to measure students' satisfaction. Kundi et al., (2014) identified tangibility and assurance as the most important factors to be considered for the improvement of service quality. The study also mentioned that it is not only the bookish knowledge to which the students of the education institutions pay attention. Parasuraman, et al., (1991) assumed that reliability was basically related to the outcome of service and the process of service delivery considered as tangibles, assurance, responsiveness and empathy. Therefore, consumer loyalty may be based on the atmosphere a service delivery method is taken in the business, while still being dependent on the site of familiarity of the process. Experience may differ depending on how the consumers' service delivery process is treated. Navarro et al. (2005) mentioned that students evaluate the quality of organization on the basis of tangibility (teachers), reliability and responsiveness (methods of teaching) and management of the institution and these factors have direct influence on the level of students' satisfaction.

\section{Objectives of the Study}

i) To understand service quality dimensions of higher education institutions.

ii) To examine the linkage service quality dimensions and students satisfaction.

\section{Conceptual Framework}

Service quality may be measured by using different dimensions. Among all the measuring instruments, SERVQUAL (Parasuraman et al., 1988) is the well-known and widely used instrument of measurement of service quality and customer satisfaction. This instrument has been used in both business and academic areas. In education sector, students are treated as customers and education service quality should logically be measured from the perspective of students (Min and Khoon, 2013). SERVQUAL instrument indicated five dimensions of service quality: tangibles, reliability, responsiveness, assurance, empathy.

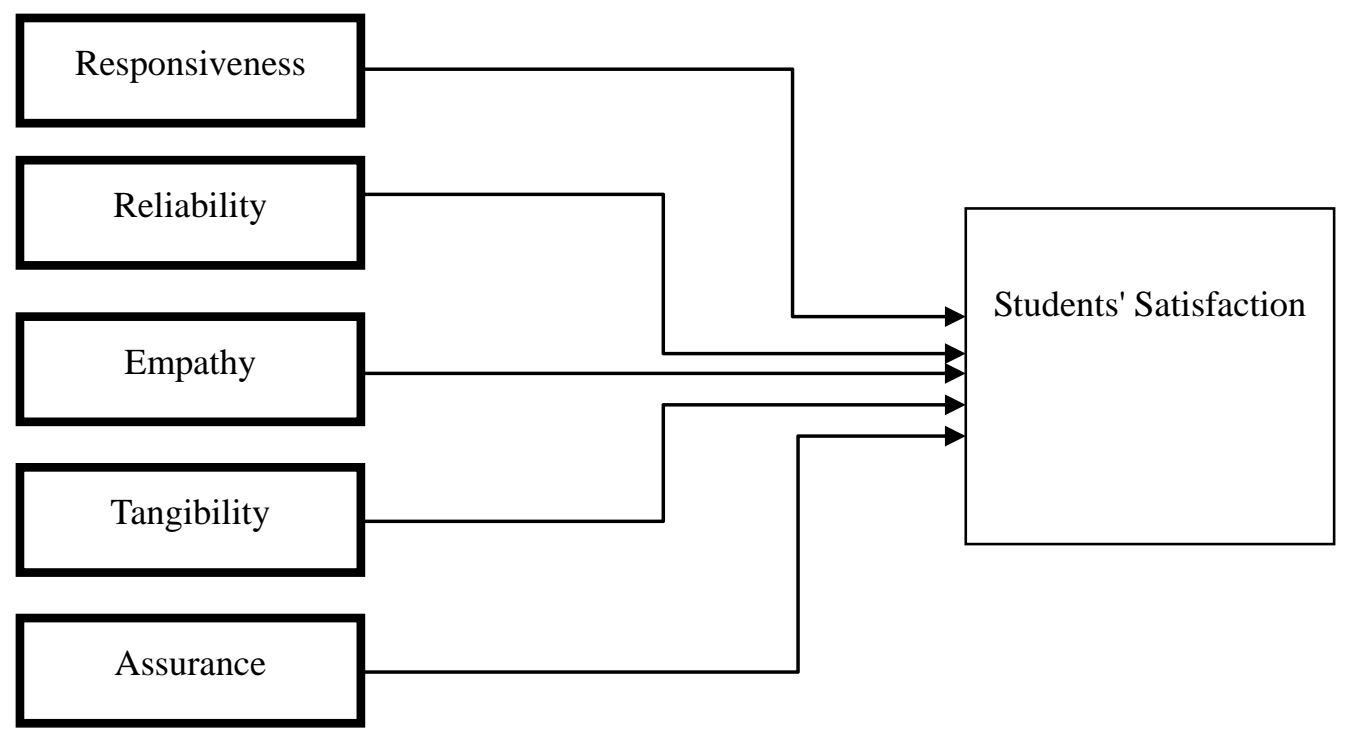

Figure 1.Service Quality Dimensions and Student's Satisfaction

a) Tangibles: the service dimension that makes a product or service practical and usable for customers. It provides physical representations of the service to evaluate quality.

b) Reliability: the ability of service supplier to promptly provide the promised service. It represents the dependability and accuracy of service quality to meet the expectation of customers.

c) Responsiveness: intention to meet the customers' demand as soon as possible. It represents the willingness to help customers for providing prompt service and feeling interest regarding customers' opinion. 
d) Assurance: the capability of service provider to build trust and confidence on the quality of service provided. It represents the promotion of customers' belief on the institution and service received.

e) Empathy: intention to meet the demand of individual customers considering their uniqueness and specialty. It represents the personalized attention of a firm to its customers.

\section{Research Methodology}

This study was adopted from Parasuraman's SERVQUAL dimensions to understand the relationship between students' satisfaction and service quality of higher education institution. In this study, students' satisfaction is dependent variable and service quality is independent variable that measures the level of satisfaction with service performance. The dimensions of service quality include tangibles, reliability, responsiveness, assurance and empathy. Eight universities including four private universities have been chosen as sample institution using purposive sampling technique. The data were collected from a sample of 207 respondents from the selected universities located in Dhaka and Chittagong. A face to face interview method is followed by using a five points Likert scale type questionnaire.

To check the reliability of the instrument, Cornbrash's reliability analysis was done. This analysis provides a value of 0.72 which is greater than acceptable level in social science i.e.0.6 and a value close to 1 provides more reliability in a range between 0 and 1 for the analysis of the data, SPSS 18.0 software has been used.

\section{Findings and Analysis}

Descriptive Analysis

Table 1, $2 \& 3$ presents the demographics of the data. From table 1, male respondents were 119, that means 57.49 percent respondents were male and the rest 42.51 percent respondents were female.

Table 1.Gender of respondents

\begin{tabular}{|l|l|l|l|}
\hline & Gender & Frequency & Percent \\
\hline Valid & Male & 119 & 57.49 \\
\cline { 2 - 4 } & Female & 88 & 42.51 \\
\cline { 2 - 4 } & Total & 207 & 100 \\
\hline
\end{tabular}

Table 2.Nature of Institution

\begin{tabular}{|l|l|l|l|}
\hline & University & Frequency & Percent \\
\hline \multirow{4}{*}{ Valid } & Public & 94 & 45.41 \\
\cline { 2 - 4 } & Private & 113 & 54.59 \\
\cline { 2 - 4 } & Total & 207 & 100 \\
\hline
\end{tabular}

Table 3. Level of study of respondents

\begin{tabular}{|l|l|l|l|}
\hline & Level of study & Frequency & Percent \\
\hline \multirow{4}{*}{ Valid } & Bachelor & 129 & 62.32 \\
\cline { 2 - 4 } & Masters & 78 & 37.68 \\
\cline { 2 - 4 } & Total & 207 & 100 \\
\hline
\end{tabular}

Table 2 shows the nature of institution of the respondents. 94 respondents (45.41\%) were taken from public universities and the rest 113 respondents were from private universities. 62.32 percent respondents were taken from Bachelor level and 37.68 percent from Masters Level. (Table 3)

Table 4. Mean and standard deviation of variables

\begin{tabular}{|c|c|c|c|}
\hline & N & Mean & Std. Deviation \\
\hline Tangible & 207 & 4.0048 & .81549 \\
Reliability & 207 & 3.6570 & .79025 \\
Responsiveness & 207 & 3.4251 & .94146 \\
Assurance & 207 & 3.6184 & .80306 \\
Empathy & 207 & 3.6570 & .77787 \\
Satisfaction & 207 & 3.9807 & .90822 \\
\hline
\end{tabular}

Table 4, presents mean value and standard deviation of service quality dimensions and students satisfaction. Mean scores of dimensions of service quality show that students are overall satisfied on the service quality dimensions. The mean value of tangible is highest $(\mathrm{M}=4.0048)$ which means that students satisfaction level depends on infrastructure namely building, location, lab and library facility, well decorated modern classroom etc. In Bangladesh, particularly many private universities do not have their own campus. They may locate at different central zone of the city, but lack of proper library, 
lab facility and infrastructure students failed to receive quality education. Owners of the universities should focus on this issue for improving the satisfaction of the students to the institution. Students also focused on the reliability and empathy to measure the satisfaction particularly skilled and experienced academic staff, accurate evaluation and record keeping, providing financial aid and scholarship, considering students problem with care. Students emphasized less on responsiveness to deliver service quickly and accurately to the students as demanded by them.

Table 5. Pearson's Correlation among service quality dimensions and students satisfaction

Correlations

\begin{tabular}{|c|c|c|c|c|c|c|c|}
\hline & & Tangible & Reliability & Responsiveness & Assurance & Empathy & Satisfaction \\
\hline \multirow[t]{3}{*}{ Tangible } & Pearson Correlation & 1 & & & & & \\
\hline & Sig. (2-tailed) & & & & & & \\
\hline & $\mathrm{N}$ & 207 & & & & & \\
\hline \multirow[t]{3}{*}{ Reliability } & Pearson Correlation & $.146^{*}$ & 1 & & & & \\
\hline & Sig. (2-tailed) & .036 & & & & & \\
\hline & $\mathrm{N}$ & 207 & 207 & & & & \\
\hline \multirow[t]{3}{*}{ Responsiveness } & Pearson Correlation & .035 & .014 & 1 & & & \\
\hline & Sig. (2-tailed) & .614 & .839 & & & & \\
\hline & $\mathrm{N}$ & 207 & 207 & 207 & & & \\
\hline \multirow[t]{3}{*}{ Assurance } & Pearson Correlation & $-.249^{* * *}$ & .060 & -.016 & 1 & & \\
\hline & Sig. (2-tailed) & .000 & .387 & .824 & & & \\
\hline & $\mathrm{N}$ & 207 & 207 & 207 & 207 & & \\
\hline \multirow[t]{3}{*}{ Empathy } & Pearson Correlation & $-.196^{* * *}$ & $-.327^{* *}$ & $-.145^{*}$ & .124 & 1 & \\
\hline & Sig. (2-tailed) & .005 & .000 & .038 & .076 & & \\
\hline & $\mathrm{N}$ & 207 & 207 & 207 & 207 & 207 & \\
\hline \multirow[t]{3}{*}{ Satisfaction } & Pearson Correlation & $.216^{* *}$ & $.140^{*}$ & .106 & .036 & .011 & 1 \\
\hline & Sig. (2-tailed) & .002 & .045 & .128 & .602 & .873 & \\
\hline & $\mathrm{N}$ & 207 & 207 & 207 & 207 & 207 & 207 \\
\hline
\end{tabular}

*. Correlation is significant at the 0.05 level (2-tailed).

** Correlation is significant at the 0.01 level (2-tailed).

Pearson's correlation technique was used to identify the relationship between six variables. Table 5 , shows a positive relationship between service quality dimensions namely tangible, reliability, responsiveness, assurance, empathy and students satisfaction. The highest correlation is found between tangibles and students satisfaction i.e. $r=.216 p<0.01$. The relationship indicates that excellent campus layout at accessible location, available class room with modern teaching aid, transport facility, computer lab and internet facility, library and cafeteria facility are associated with students satisfaction on higher education institution. There is also a significant positive relation between reliability and students satisfaction i.e. $\mathrm{r}=.140 \mathrm{p}<0.05$. That means students satisfaction depends on transparent evaluation and recording system of students result, skilled and experienced academic staff, maintaining well organized academic calendar, standard and updated curriculum of the institution. It is also seen that other dimensions namely, responsiveness, assurance and empathy have positive correlation but the correlation is not significant.

\section{Conclusion}

In Bangladesh, higher education is becoming more competitive with the remarkable increase in the number of private academic institutions. The overall quality has not yet achieved at the desired level though many are trying to improve and taking several initiatives. The present study mainly focused on assessing the relationship between service quality dimensions (tangibles, reliability, responsiveness, assurance, empathy) and students' satisfaction. It is found that all the dimensions of service quality have positive relation with students satisfaction particularly tangibles and reliability have significant influence to measure students satisfaction on higher education institution. Students' satisfaction depends on modern classroom facility, computer lab, internet facility, transport facility, library facility, campus layout and location etc. Students expect skilled and experienced academic staff, transparent evaluation and recording system, maintaining proper academic calendar, standard course content. Students' satisfaction also enhanced by proper support from administration, financial aid, seminar, workshop, extracurricular facilities. Higher education institutions need to focus on quality issues 
and supervise it for increase students' satisfaction.

\section{Limitations and Future Research}

This study inundates a number of limitations and potential specific directions for future research. The most significant limitation is the sample size which was small. The research would have been more reliable if a greater size of the sample had been used. Response of students from higher education institution located outside Dhaka and Chittagong are not considered in the study. Limitations also included time and cost constraints. It highly recommends future research to address all these concerns as much as possible.

\section{References}

Alves, H., \&Raposo, M. (2010).The influence of university image on students' behavior.International journal of education management,24(1), 73-85.https://doi.org/10.1108/09513541011013060

Angell, R., Heffernan, T., \&Megicks,P. (2008).Service quality in postgraduate education.Quality assurance in education, 16(3), 236-54.https://doi.org/10.1108/09684880810886259

Asaduzzaman., H. M., \&Rahman, M. (2013). Service quality and student satisfaction: a case study on private universities in Bangladesh. International journal of economics, finance and management sciences, 1(3), 128-135.

Athiyaman, A. (1997). Linking student satisfaction and service quality perceptions; the case of university education.European journal of marketing,31(3), 528-540.https://doi.org/10.1108/03090569710176655

Crawford, L. E. D., \&Shulter, P. (1999). Total quality management in education: problems and issues for the classroom teacher. The internal journal of education management, 13(2), 67-73.https://doi.org/10.1108/09513549910261122

Das, D., \&Haque, H. M. J. (2013). Faculty service towards student satisfaction in tertiary education: Bangladesh perspective. Knowledge horizons-Economics, 5(4), 220-230.

Elliot, K., \& Shin, D. (2002). Student satisfaction: An alternative approach to assessing this important concept. Journal of higher education policy and management,24, 197-209.https://doi.org/10.1080/1360080022000013518

Emercy, C., Kramer, T., \&Tian, R. (2001). Customer vs. product: adopting an effective approach to business students. Quality assurance in education,9(2), 110-115.https://doi.org/10.1108/09684880110389681

Faruky, K. N. B., Uddin, M. A., \&Hossain, T. (2012). Students' satisfaction: A study among private university students of Bangladesh. World journal of social sciences,2(4).

Gecer, A. (2013). Lecturer-student communication in blended learning environments.Educationalsciences: theory and practice, 13(1), 362-297.

Gronroos, C. (1982). A service quality model and its marketing implications.European journal of marketing,18(4), 36-44.https://doi.org/10.1108/EUM0000000004784

Huda, S.S., Akhtar, A., \& Ahmad, J.U. (2010).The state of private universities in Bangladesh: An evaluation of students' perception.Information management and business review, 1(1), 16-27.https://doi.org/10.22610/imbr.v1i1.868

Jain, R., Sinha, G., \&Sahney, S. (2011). Conceptualizing service quality in higher education.Asian journal on quality, 12(3), 296-314.https://doi.org/10.1108/15982681111187128

Kang, S.S., O. Nobuyuki, \& D. Herbert.(2004). Service Quality and itsEffects on CustomerSatisfaction and Customer Behavioral Intention:Hotel and Ryokan Guests in Japan. Asia Pacific Journal of Tourism Research, 9(2), 189-203.https://doi.org/10.1080/1094166042000233649

Khan, M. M., Ahmed, I., \& Nawaz, M. M. (2011). Student's perspective of service quality in higher learning institutions; an evidence based approach. International journal of business and social science, 2(11), 159-164.

Kotler, P., \& Clarke, R.N. (1987).Marketing for health care organizations.Englewood Cliffs, NJ: Prentice-Hall, 1987.

Kundi, G. M., Qureshi, Q. A., Khan, Y., \&Akhtar, R. (2014).Impact of service quality on customer satisfaction in higher education institutions.Industrial engineering letters,4(3), 23-28.

Majid, A.K.M.S., Mamun, M.Z., \&Siddique, S.R. (2000).Practices of teaching methods, aids andstudents' performance evaluation.

Malik, M. E., Danish, R. Q. D., \&Usman, A. (2010).The impact of service quality on students' satisfaction in higher education institute of Punjab.Journal of management research,2(2),1-11.https://doi.org/10.5296/jmr.v2i2.418

Mark, E. (2013). Student satisfaction and the customer focus in higher education. Journal of higher education policy and management, 35(1), 2-10.https://doi.org/10.1080/1360080X.2012.727703 
Min, S., \&Khoon, C.C. (2013). Demographic factors in the evaluation of service quality in higher: International students' perspective. International review of management and business research, 2(1).https://doi.org/10.5539/ijms.v6n1p90

Navarro, M. M., Iglesias, M. P., \& Torres, P. R. (2005).Measuring customer satisfaction in summer courses.Quality assurance in education,13(1), 53-65.https://doi.org/10.1108/09684880510578650

Parasuraman, A., Berry, L. L., \&Zeithaml, V. A. (1991). Perceived service quality as a customer based performance measure: an empirical examination of organizational barriers using an extended service quality model. Journal of Human resource management,30(3), 335-364.https://doi.org/10.1002/hrm.3930300304

Parasuraman, A., Zeithmal, V. A., \& Berry, L. L. (1988). SERVQUAL: A multiple-item scale for measuring customer perceptions of service quality. Journal of retailing,64(1), 12-40.

Uka.A. (2014).Student satisfaction as an indicator of quality in higher education.Journal of education and instructional studies in the world, 4(3), 6-10.

Zeithaml, V.A. (1988). Consumer perceptions of price, quality and value: a means-end model and synthesis of evidence. Journal of marketing, 52, 2-22.https://doi.org/10.1177/002224298805200302

\section{Copyrights}

Copyright for this article is retained by the author(s), with first publication rights granted to the journal.

This is an open-access article distributed under the terms and conditions of the Creative Commons Attribution license which permits unrestricted use, distribution, and reproduction in any medium, provided the original work is properly cited. 